Article

\title{
Sorafenib in Combination with Betulinic Acid Synergistically Induces Cell Cycle Arrest and Inhibits Clonogenic Activity in Pancreatic Ductal Adenocarcinoma Cells
}

\author{
Justyna Kutkowska, Leon Strzadala and Andrzej Rapak * \\ Department of Experimental Oncology, Ludwik Hirszfeld Institute of Immunology and Experimental Therapy \\ Polish Academy of Science, 53-114 Wroclaw, Poland; justyna.kutkowska@iitd.pan.wroc.pl (J.K.); \\ strzadal@iitd.pan.wroc.pl (L.S.) \\ * Correspondence: rapak@iitd.pan.wroc.pl; Tel.: +48-71-3371172
}

Received: 24 August 2018; Accepted: 16 October 2018; Published: 19 October 2018

\begin{abstract}
Pancreatic ductal adenocarcinoma (PDAC) is one of the most deadly cancers in the world due to late diagnosis and poor response to available treatments. It is important to identify treatment strategies that will increase the efficacy and reduce the toxicity of the currently used therapeutics. In this study, the PDAC cell lines AsPC-1, BxPC-3, and Capan-1 were treated with sorafenib and betulinic acid alone and in combination. We examined the effect of combined treatments on viability (MTS test), proliferation and apoptosis (annexin V staining), cell cycle arrest (PI staining), alterations in signaling pathways (Western blotting), and colony-forming ability. The combination of sorafenib with betulinic acid inhibited the viability and proliferation of PDAC cells without the induction of apoptosis. The antiproliferative effect, caused by G2 cell cycle arrest, was strongly associated with increased expression of p21 and decreased expression of c-Myc and cyclin D1, and was induced only by combined treatment. Additionally, decreased proliferation could also be associated with the inhibition of the P13K/Akt and MAPK signaling pathways. Importantly, combination treatment reduced the colony-forming ability of PDAC cells, as compared to both compounds alone. Collectively, we showed that combined treatment with low concentrations of sorafenib and betulinic acid had the capacity to inhibit proliferation and abolish clonogenic activity in PDAC cell lines.
\end{abstract}

Keywords: pancreatic ductal adenocarcinoma; combination therapy; sorafenib; betulinic acid; clonogenic activity

\section{Introduction}

Pancreatic ductal adenocarcinoma (PDAC) is one of the most deadly cancers of the digestive system worldwide [1]. Pancreatic cancer affects both men and women, and the overall five-year survival rate remains below 5\% [2]. Chemotherapy is an important therapeutic method, but the sensitivity is low due to increasing drug resistance [3]. This situation is probably caused by the specific tumor microenvironment of pancreatic cancer.

Currently, gemcitabine is used as a standard therapy for advanced pancreatic cancer. However, gemcitabine alone is not very effective and is associated with drug resistance [4]. In view of that problem, developing new agents and innovative approaches are a continuing research effort to advance the treatment of this disease [5].

We have previously shown that combination treatment with sorafenib (SOR) and betulinic acid (BA) inhibits proliferation, induces cell death, and reduces colony-forming ability in non-small cell lung cancer (NSCLC) cell lines with different KRAS mutations [6]. In pancreatic cancer, activating 
KRAS mutations occur at a frequency of $90 \%$ [7]. Previous studies have shown that almost all therapies targeting KRAS mutations have failed [8]. Many efforts have been made in the field of PDAC therapies to develop drugs or combination of drugs targeting the components of the downstream effector pathways of KRAS signals, such as the MAPK and PI3K/Akt signaling pathways [9].

Sorafenib (SOR) is an oral, multitargeted kinase inhibitor directed against the mitogen-activated protein kinase (MAPK) pathway, vascular endothelial growth factor receptor-2 (VEGFR-2) and -3 (VEGFR-3), platelet-derived growth factor receptor-b (PDGFRb), Fms-related tyrosine kinase 3 (FLT3), and mast/stem cell growth factor receptor Kit (c-KIT) [10,11]. Sorafenib is approved for the treatment of renal cell carcinoma, hepatocellular carcinoma, and thyroid cancer [12,13]. The data suggest that sorafenib has a potential therapeutic benefit for PDAC treatment; however, the results of a combination therapy utilizing sorafenib with gemcitabine or sorafenib with erlotinib indicated that sorafenib was not able to enhance chemotherapeutic effect [14,15].

Several anticancer and anti-infectious drugs are derived from natural products [16]. Betulinic acid (BA) is a natural pentacyclic triterpene with a lupine structure isolated from the bark of the white birch (Betula pubescens) [17]. BA has been shown to induce apoptosis in a p53- and caspase-independent manner, mitochondrial membrane alteration, and DNA fragmentation [18]. Importantly, some reports showed that BA induced cell death by downregulating the expression of the P13K/Akt signaling pathway [19]. BA exhibits significant antitumor activities in various cancer cells, including pancreatic cancer [20].

In this study, we showed that combination treatment with SOR and BA also reduced the clonogenic potential of PDAC cells, suppressed proliferation via cell cycle arrest, and inhibited the PI3K/Akt and MAPK signaling pathways, but it did not induce apoptosis. Combination therapies that act on different molecular targets in the cancer should increase the probability of cancer elimination and decrease the development of resistant cancer cells.

\section{Results}

2.1. The Combination of Sorafenib and Betulinic Acid Inhibits the Proliferation of PDAC Cell Lines, but Does Not Induce Apoptosis

Recently, we have shown that combination treatment with SOR and BA caused significant proliferation-inhibitory effects in NSCLC cell lines [6]. We first investigated the effects of SOR and BA on cell viability using the MTS assay to determine whether their combination can inhibit the proliferation of human PDAC cell lines with different mutational KRAS status (Table 1). Treatment of BxPC-3 cells with SOR and BA resulted in dose-dependent growth inhibition, but two other cell lines, AsPC-1 and Capan-1, were resistant to treatment with SOR and BA after $72 \mathrm{~h}$. Next, PDAC cell lines were treated with sorafenib (AsPC-1 and Capan-1, $5 \mu \mathrm{M}$; BxPC-3, $3 \mu \mathrm{M}$ ) and betulinic acid $(6 \mu \mathrm{M})$ alone or in combination for $72 \mathrm{~h}$. SOR and BA alone decreased cell viability by an average of $73.4 \pm 13.6 \%$ and $83.5 \pm 10.8 \%$ in AsPC- 1 cells, $84.8 \pm 10.9 \%$ and $72.3 \pm 13.2 \%$ in BxPC-3 cells, $81.1 \pm 12.2 \%$ and $101.8 \pm 8.7 \%$ in Capan- 1 cells, respectively, but combination treatment reduced cell viability more effectively to $59.8 \pm 3.7 \%(\mathrm{CI}=0.829)$ in AsPC-1 cells, $42.2 \pm 10.1 \%(\mathrm{CI}=0.633)$ in BxPC-3 cells, and $59.7 \pm 5.7 \%(\mathrm{CI}=0.409)$ in Capan-1 cells (Figure 1A).

Table 1. Mutational status of pancreatic ductal adenocarcinoma (PDAC) critical genes [21,22].

\begin{tabular}{ccc}
\hline \multirow{2}{*}{ PDAC Cell Line } & \multicolumn{2}{c}{ Oncogenes } \\
\cline { 2 - 3 } & KRAS & BRAF \\
\hline AsPC-1 & G12D & wt \\
BxPC-3 & wt & V487-P492 $>A$ \\
Capan-1 & G12V & wt \\
\hline \multicolumn{3}{c}{ wt-wild-type. }
\end{tabular}



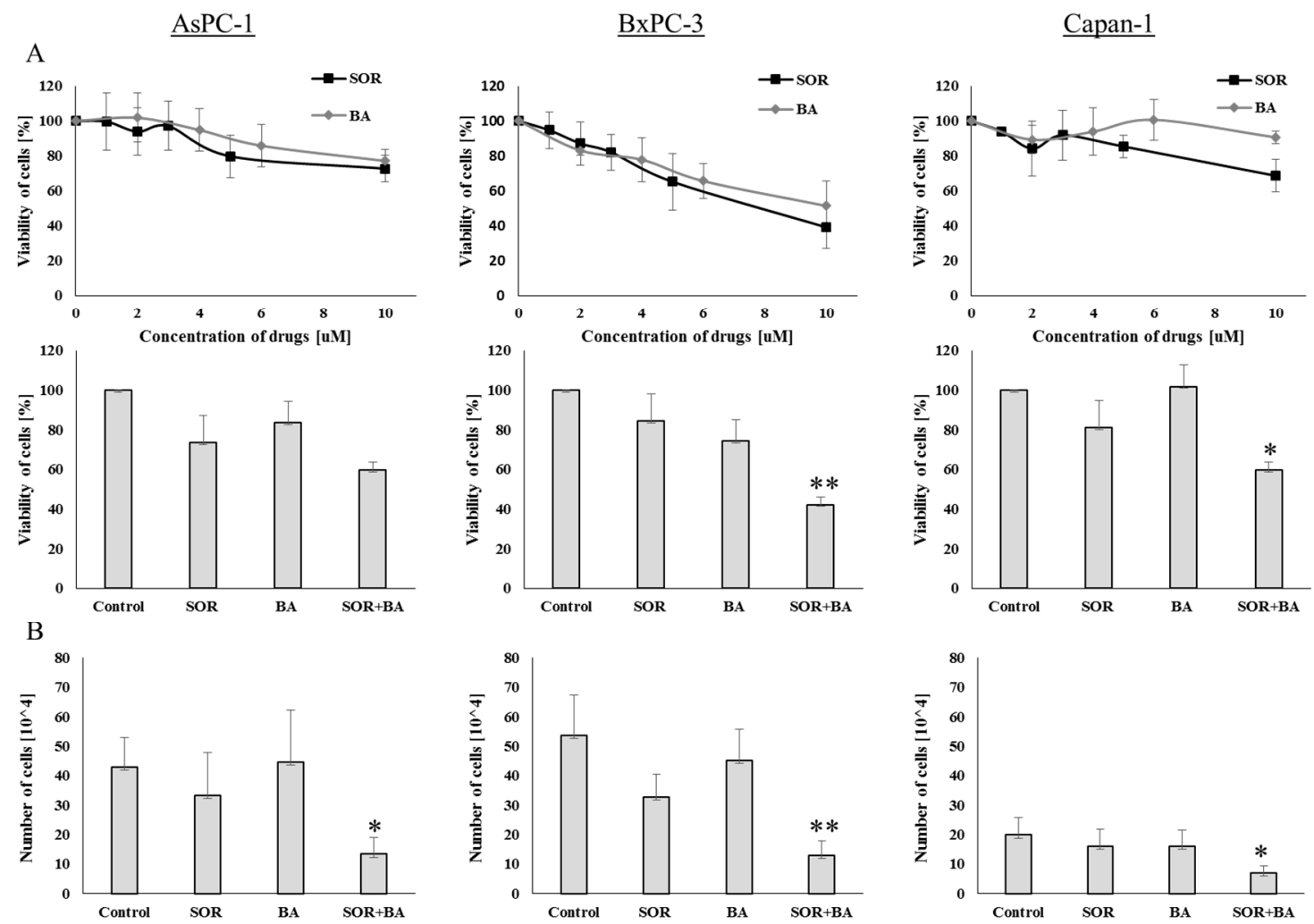

Figure 1. Effect of combination treatment with sorafenib (SOR) and betulinic acid (BA) on cell growth inhibition of PDAC cell lines. (A) Viability of AsPC-1, BxPC-3, and Capan-1 cells after exposure to sorafenib and betulinic acid at different drug concentrations (AsPC-1 and Capan-1: $5 \mu \mathrm{M}, \mathrm{BxPC}-3$ : $3 \mu \mathrm{M})$ and betulinic acid $(6 \mu \mathrm{M})$ alone and in combination. (B) The number of AsPC-1, BxPC-3, and Capan- 1 cells after treatments with sorafenib (AsPC-1 and Capan-1: $5 \mu \mathrm{M}, \mathrm{BxPC}-3: 3 \mu \mathrm{M}$ ) and betulinic acid $(6 \mu \mathrm{M})$ alone and in combination $(n=4)$. Data are presented as means \pm SD normalized to the untreated control. ${ }^{*} p<0.05,{ }^{* *} p<0.01$ compared with the sorafenib treatment group and betulinic acid treatment group.

We subsequently investigated whether the combination of SOR and BA could inhibit PDAC cell proliferation using trypan blue staining. As shown in Figure 1B, combination treatment significantly reduced the number of cells from $45.5 \pm 12.7 \times 10^{4}$ to $13.3 \pm 5.5 \times 10^{4}(\mathrm{CI}=0.229)$ in AsPC- 1 cells, from $46.8 \pm 8.2 \times 10^{4}$ to $13.02 \pm 4.9 \times 10^{4}(\mathrm{CI}=0.198)$ in BxPC-3 cells, and from $18.2 \pm 3.8 \times 10^{4}$ to $6.9 \pm 2.5 \times 10^{4}(\mathrm{CI}=0.272)$ in Capan-1 cells, as compared to either compound alone $(p<0.05)$.

Additionally, we used the annexin V-FIC/PI double staining and apoptosis-associated DNA fragmentation by staining cells with propidium iodide (PI) to evaluate whether the SOR and BA combination induced apoptosis in PDAC cells. As shown in Figure 2, combination treatment did not increase apoptosis in PDAC cell lines.

\subsection{The Combination of Sorafenib and Betulinic Acid Induces G2 Cell Cycle Arrest in AsPC-1 Cells}

The cell cycle distribution analysis was performed using flow cytometry to elucidate how the combination of SOR and BA inhibited cell proliferation. The results showed that the combination of SOR and BA significantly induced cell cycle arrest at G2 phase (Figure 3A). The percentage of G2 phase cells increased to $39 \%$ after treatment with the SOR and BA combination. 
A

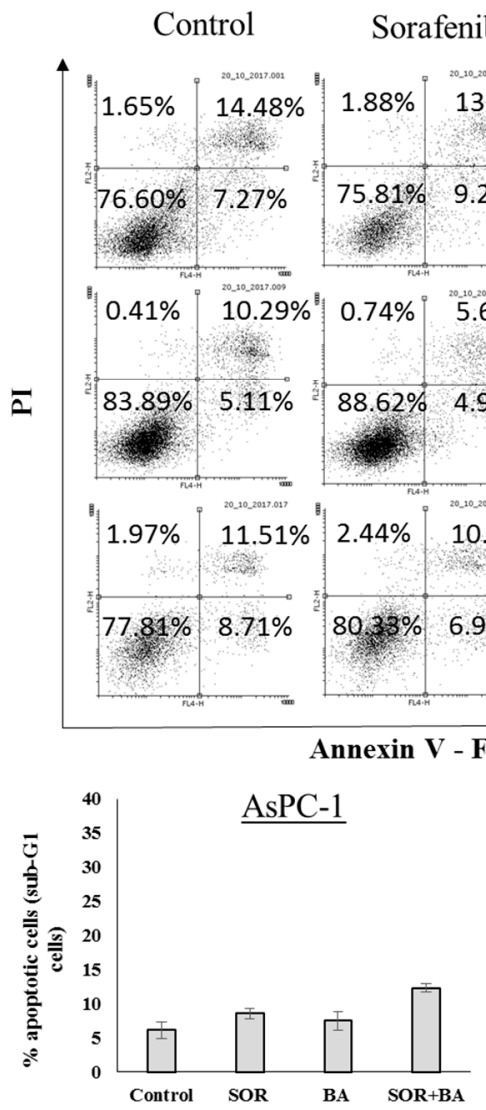

B
Betulinic Acid SOR+BA
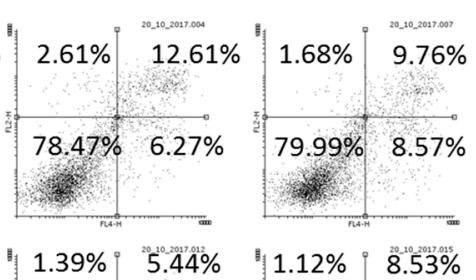

$89.83 \% \quad 3.34 \%$
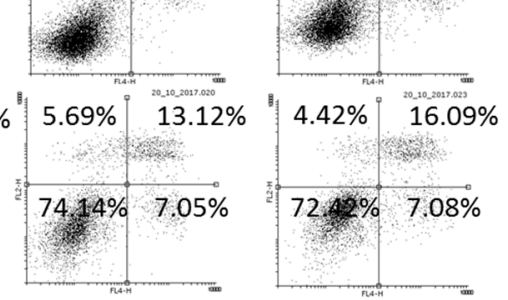
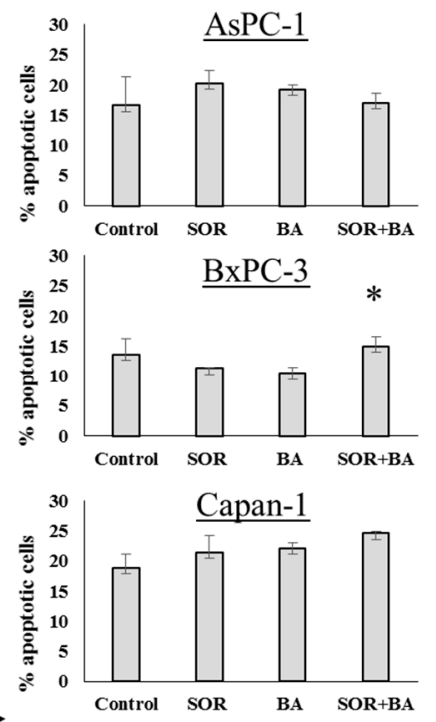
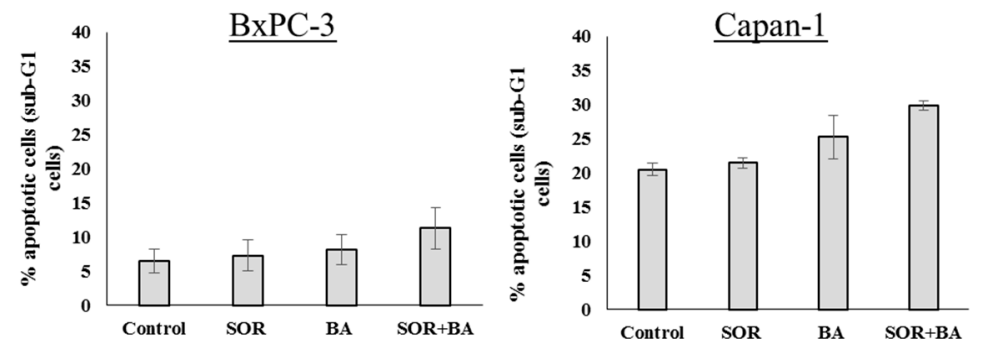

Figure 2. Cytotoxicity effect of combination treatment with SOR and BA on PDAC cells. (A) Representative FACS dot plots showing the effect of combination treatment with sorafenib (AsPC-1 and Capan-1: $5 \mu \mathrm{M}, \mathrm{BxPC}-3: 3 \mu \mathrm{M})$ and betulinic acid $(6 \mu \mathrm{M})$ on phosphatidylserine exposure and plasma membrane integrity after $72 \mathrm{~h}$ of incubation with pancreatic cancer cells, as determined by annexin V-FIC/PI staining. (B) Apoptosis-associated DNA fragmentation of AsPC-1, BxPC-3, and Capan-1 cells after treatments with sorafenib (AsPC-1 and Capan-1: $5 \mu \mathrm{M}$, BxPC-3: $3 \mu \mathrm{M}$ ) and betulinic acid $(6 \mu \mathrm{M})$ alone and in combination $(n=3)$. Data are presented as means $\pm \mathrm{SD}$. ${ }^{*} p<0.05$ compared with the sorafenib treatment group and betulinic acid treatment group.

The effect was further confirmed by the detection of key proteins that help regulate the cell cycle. Figure 3B shows that the level of p21 increased after treatment with SOR and BA alone and in combination for $24 \mathrm{~h}$, while the levels of c-Myc and cyclin D1 decreased after combination treatment. However, the expression of cyclin B1 remained unchanged. These results suggest that cell cycle arrest in the G2 phase is a probable mechanism by which SOR + BA prevent PDAC cell proliferation. The results were similar in the other two cell lines.

2.3. Combination Treatment with Sorafenib and Betulinic Acid Inhibits the Expression of the PI3K/Akt and MAPK Signaling Pathways in the AsPC-1 and BxPC-3 Cell Lines

We investigated the effects of SOR and BA alone and in combination on the PI3K/Akt and/or MAPK signaling pathways in AsPC- 1 and BxPC-3 cells, because the activation of these pathways is important for cell cycle progression in human pancreatic cancer cells [23,24]. Western blotting results showed (Figure 4) that combination treatment inhibited ERK1/2 phosphorylation after 24 and $72 \mathrm{~h}$ in BxPC-3 cells. In addition, combination treatment inhibited the expression and phosphorylation of Akt after $72 \mathrm{~h}$ in AsPC-1 cells and after 24 and $72 \mathrm{~h}$ in BxPC-3 cells. 


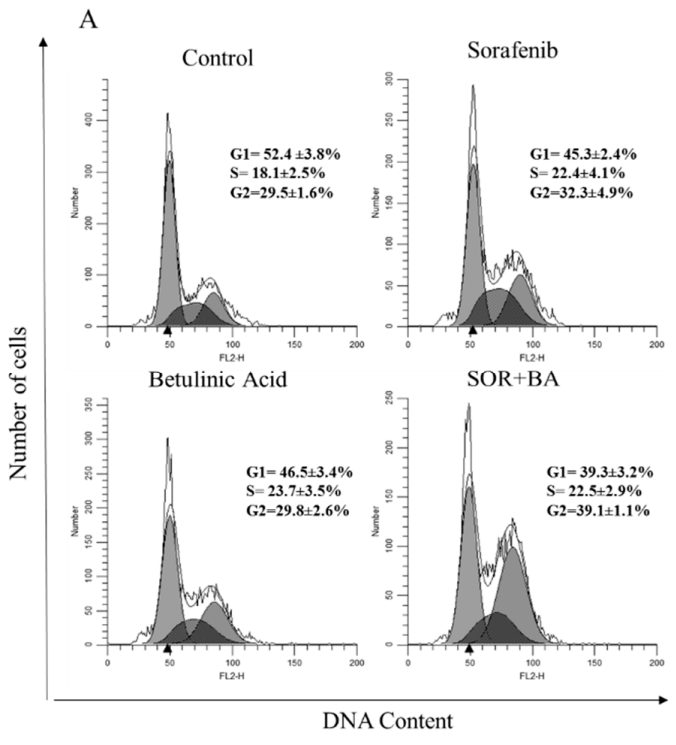

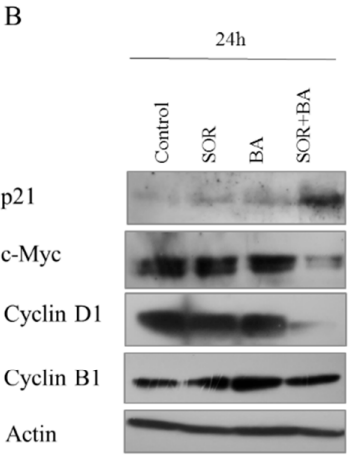
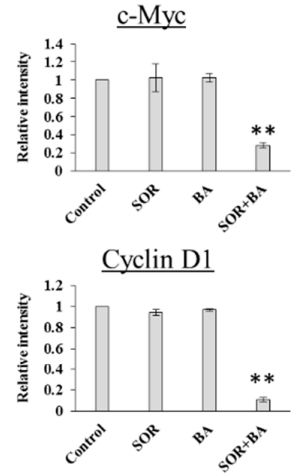

p21

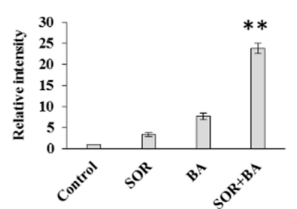

Cyclin B1

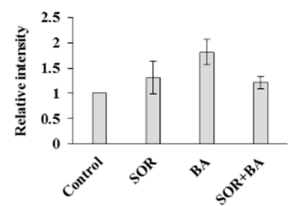

Figure 3. Effect of combination treatment with SOR and BA on cell cycle arrest in AsPC-1 cells. (A) Representative cell cycle analyzed by FACS of AsPC-1 cells after treatments with sorafenib $(5 \mu \mathrm{M})$ and betulinic acid $(6 \mu \mathrm{M})$ alone and in combination $(n=3)$. (B) Representative immunoblot of p21, c-Myc, cyclin D1, and cyclin B1 expression from AsPC-1 cells treated with sorafenib $(5 \mu \mathrm{M})$ and betulinic acid $(6 \mu \mathrm{M})$ alone and in combination $(n=3)$. Actin served as a loading control. Data are presented as means $\pm \mathrm{SD} .{ }^{*} p<0.05,{ }^{* *} p<0.01$ compared with the sorafenib treatment group and betulinic acid treatment group. All experiments were repeated at least three times.
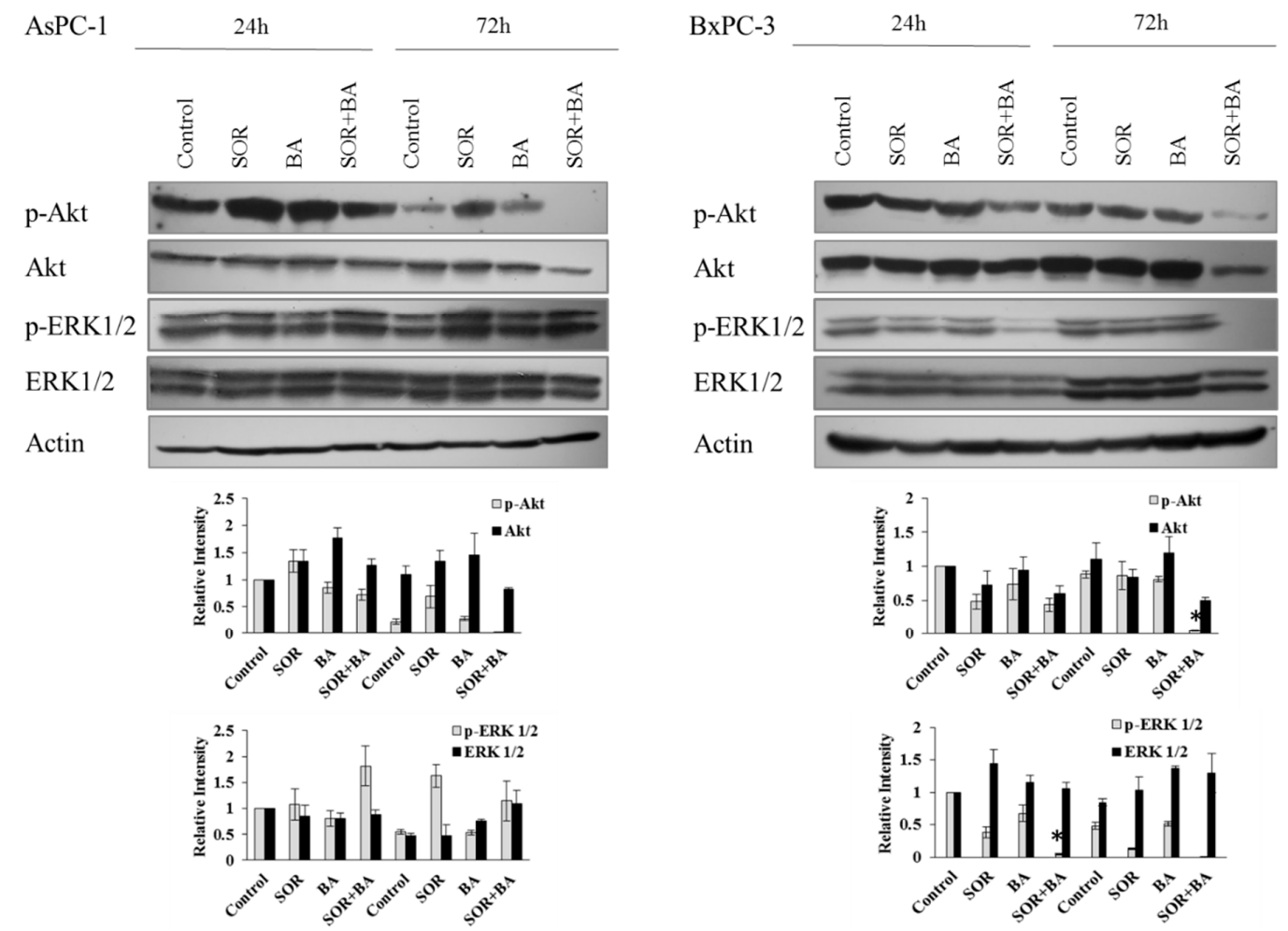

Figure 4. The effect of combination treatment with SOR and BA on protein expression of the PI3K/Akt and MAPK signaling pathways in human PDAC cell lines-AsPC-1 and BxPC-3. Representative immunoblot of phospho-Akt (Ser473), Akt, phospho-ERK1/2, and ERK1/2 expression from AsPC-1 and BxPC-3 cells treated with sorafenib (AsPC-1: $5 \mu \mathrm{M}, \mathrm{BxPC}-3: 3 \mu \mathrm{M}$ ) and betulinic acid $(6 \mu \mathrm{M})$ alone and in combination $(n=3)$. Actin served as a loading control. Data are presented as means \pm SD. ${ }^{*} p<0.05$ compared with the sorafenib treatment group and betulinic acid treatment group. 


\subsection{The Combination of Sorafenib and Betulinic Acid Reduces the Colony-Forming Ability of PDAC Cell Lines}

The long-term assay (clonogenic survival) was employed to determine the ability of combination treatment with SOR and BA to influence pancreatic cancer cell survival. PDAC cell lines were treated with sorafenib (AsPC-1 and Capan-1: $5 \mu \mathrm{M}$, BxPC-3: $3 \mu \mathrm{M})$ and betulinic acid $(6 \mu \mathrm{M})$ alone or in combination for 14 days, after which the number of colonies formed was counted (Figure 5). The SOR and BA combination significantly reduced the number of colonies (surviving fraction) compared to the control and single sorafenib and betulinic acid treatments for all cell lines. In addition to reducing the number of colonies, colony size appeared to be smaller in the SOR+BA treatment, suggesting that the combination also prevented the clonogenic expansion of existing tumor cells.
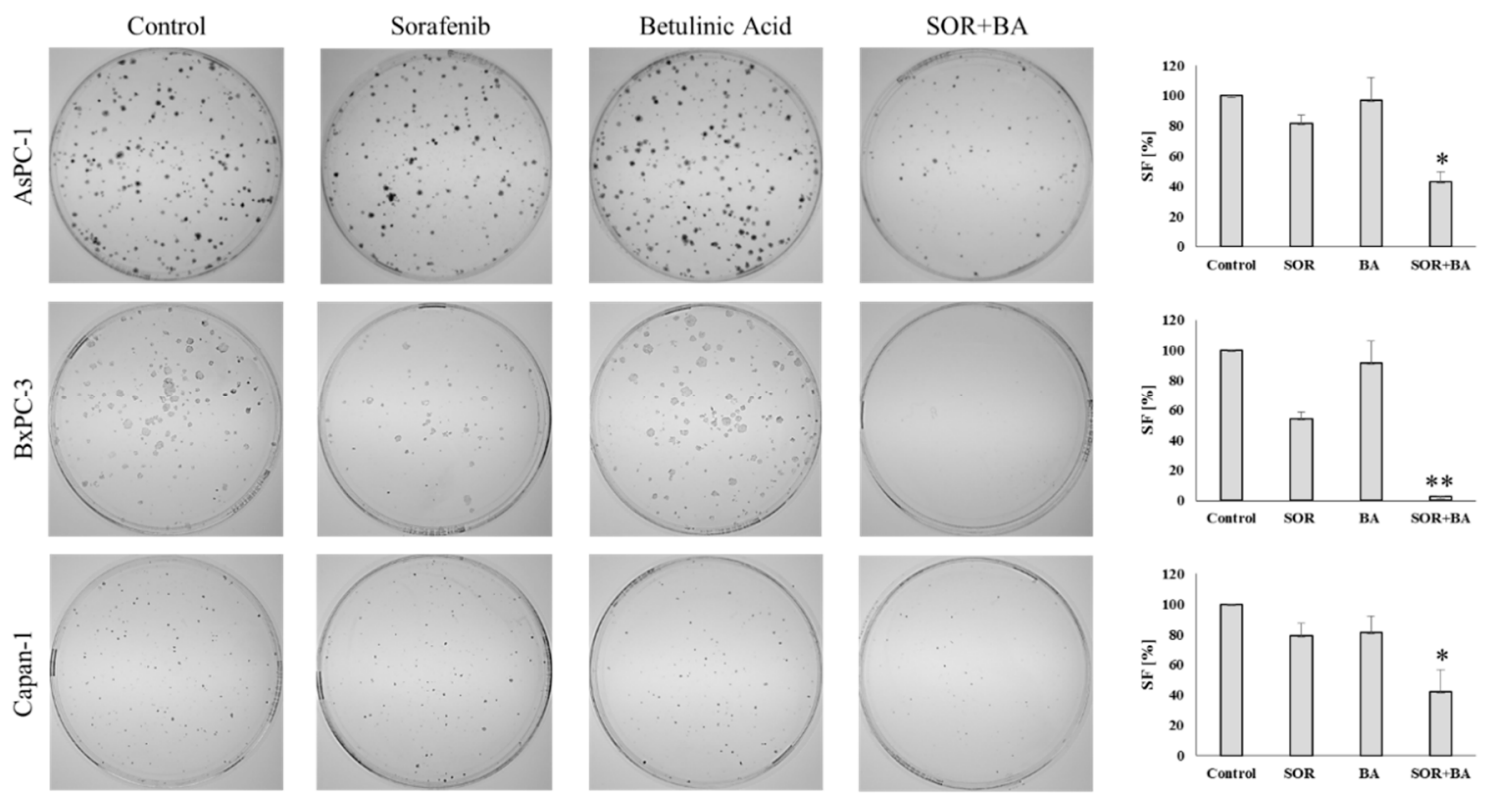

Figure 5. Effect of combination treatment with SOR and BA on the colony-forming ability of AsPC-1, BxPC-3, and Capan-1 cell lines. On the left: representative images of colonies formed by AsPC-1, BxPC-3, and Capan-1 cells after treatment with sorafenib (AsPC-1 and Capan-1: $5 \mu \mathrm{M}, \mathrm{BxPC}-3: 3 \mu \mathrm{M}$ ) and betulinic acid $(6 \mu \mathrm{M})$ alone and in combination. On the right: the surviving fraction (SF) of AsPC-1, BxPC-3, and Capan-1 cells after treatment with sorafenib (AsPC-1 and Capan-1: $5 \mu \mathrm{M}, \mathrm{BxPC}-3: 3 \mu \mathrm{M}$ ) and betulinic acid $(6 \mu \mathrm{M})$ alone and in combination $(n=3) .{ }^{*} p<0.05{ }^{* *} p<0.01$ compared with the sorafenib treatment group and betulinic acid treatment group.

\section{Discussion}

There are limited effective treatments for patients with pancreatic cancer. Gemcitabine combined with other adjuvants has been used to treat PDAC, but these approaches have had limited success and only extended life span by months with additional toxicity $[25,26]$. Several combination therapies with sorafenib, such as SOR with gemcitabine and erlotinib, have been evaluated in clinics; however, the outcomes were disappointing $[14,15,27,28]$. In addition, SOR has already been shown to exert no benefit for survival or other efficacy parameters in locally advanced or metastatic pancreatic adenocarcinoma [29]. Furthermore, Pandita et al. [20] showed that the combination of betulinic acid and gemcitabine inhibited cell proliferation, induced apoptosis, and downregulated the expression of PKM2 in PDAC cell lines. Moreover, betulinic acid was shown to have broad antitumor effects on PDAC cells in some other studies [30-32].

In this study, we determined that the natural product betulinic acid enhanced the effects of sorafenib in PDAC cell lines. Single treatment with SOR or BA shows dose-dependent growth inhibition only in the BxPC-3 cell line, whereas AsPC-1 and Capan-1 are highly resistant. Increased sensitivity of BxPC-3 cells can be caused by the presence of a mutation in BRAF, which is a possible 
target of sorafenib. We found that SOR in combination with BA significantly inhibited the proliferation, promoted cell cycle arrest, and reduced the colony-forming ability of PDAC cells in vitro. Interestingly, this combination did not induce apoptosis.

Our data showed that combination treatment with SOR and BA increased the expression of p21 and simultaneously decreased the expression of c-Myc and cyclin D1. Some authors also reported that cyclin D1 was involved in G2 arrest, especially under high levels of oxidative stress [33]. Hitomi et al. suggested that the elevated cyclin D1 level in the G2 phase was a critical checkpoint for the progression of the cell cycle [34]. Suppression of cyclin D1 levels during the G2 phase promoted the inhibition of proliferation [35]. The c-MYC proto-oncogene is activated in many PDAC cases and plays a central role in many cellular processes, such as proliferation, differentiation, and apoptosis [36]. Moreover, c-Myc overexpression was reported to be associated with gemcitabine resistance [37]. According to some reports, c-Myc inhibition was not always associated with cell death [38]; in vivo, c-Myc correlated inversely with p21 expression. The level of c-Myc determines if p21 is induced or suppressed and whether cells undergo apoptosis or growth arrest [39]. Increased p21 expression is associated with cell cycle arrest, proliferation inhibition, and cell senescence [40]. Cell cycle regulators, including p21, p27, and cyclins, should be tightly controlled; p21 coordinates with p27, thereby modulating the expression of cyclin D1 and E2 [40]. Deregulation of cyclin D1 can lead to genetic instability in in vitro and in vivo tumorigenesis [41]. Additionally, cyclin D1 overexpression is an independent prognostic factor for survival in patients with PDAC [42].

$\mathrm{PI} 3 \mathrm{~K} / \mathrm{Akt}$ and MAPK/ERK are two of the early signaling pathways of cell cycle progression [28,43]. In this study, we demonstrated that combination treatment with SOR and BA inhibited pancreatic cancer cell cycle progression by inactivating PI3K/Akt and MAPK signaling. Recently published data have shown a synergic effect between sorafenib and HS-173 (a novel PI3K inhibitor). This treatment, by synergistically inhibiting the MAPK and PI3K/Akt pathways, induced G2/M arrest and increased apoptosis in pancreatic cancer cells [44]. However, while concurrent treatment with MEK and PI3K inhibitors has recently been investigated in mouse models of pancreatic cancer, only low antitumor activity was observed $[45,46]$. Moreover, a clinical trial of MEK and PI3K inhibitor combinations also suggested that normal tissue toxicity may limit this combination [40]. A clinical study of Akt and ERK inhibitor combinations needs to be conducted to determine whether targeting ERK rather than MEK will overcome these limitations.

Mechanisms of growth suppression by signaling inhibitors are usually characterized using short-term analyses, yet clinical application of such inhibitors involves persistent long-term treatment. In the present study, we performed a long-term clonogenic survival assay. Combination treatment with SOR and BA markedly decreased the colony-forming capability of PDAC cells. This treatment has been shown previously to be nontoxic for normal human peripheral blood lymphocytes [6]. It should be noted that tumor cell cloning efficiency is positively correlated with proliferation and self-renewal abilities, which may be associated with cell tumorigenesis [47]. Studying tumor clonogenic/stem-like cells contributes to the identification of molecular targets important in successful cancer therapy [48].

In summary, we have demonstrated for the first time that combination treatment with SOR and BA can more effectively attenuate cell proliferation, promote cell cycle arrest, and reduce colony-forming ability than a single treatment in human PDAC cell lines. Moreover, combined treatment with SOR and BA can inhibit phosphorylation of Akt and ERK1/2 more potently than their individual use, which may account for the synergistic antitumor effect of this combination treatment. This study may provide a novel indication for pancreatic cancer treatment. 


\section{Materials and Methods}

\subsection{Cell Culture and Reagents}

Pancreatic ductal adenocarcinoma lines with different types of mutations (AsPC-1, BxPC-3, and Capan-1) were purchased from the American Type Culture Collection (Manassas, VA, USA) and cultured in the recommended growth media with 10\% FBS (Gibco, Thermo Fisher Scientific, Waltham, MA, USA) and antibiotic/antimycotic solution (Sigma-Aldrich, St. Louis, MO, USA). All cell lines were cultured at $37^{\circ} \mathrm{C}$ in a humidified atmosphere of $5 \% \mathrm{CO}_{2}$. The cells were seeded at densities of $1 \times 10^{4}$ cells $/ 0.1 \mathrm{~mL}\left(0.32 \mathrm{~cm}^{2}\right)$ (cell viability assay), $6 \times 10^{4}$ cells $/ 0.5 \mathrm{~mL}\left(1.9 \mathrm{~cm}^{2}\right)$ (flow cytometry), $1 \times 10^{5}$ cells $/ 3 \mathrm{~mL}\left(9.5 \mathrm{~cm}^{2}\right)$ (long-term colony formation assay, serial replating assay), and $1 \times 10^{6}$ cells $/ 4 \mathrm{~mL}\left(21 \mathrm{~cm}^{2}\right)$ (Western blotting). The cells were treated with sorafenib (LC Laboratories), betulinic acid (Sigma-Aldrich Chemistry, St. Louis, MO, USA), and both at one day post-seeding. The cells were collected for the appropriate assay three days later.

\subsection{Cell Viability Assay}

Cell viability was assessed by the CellTiter 96 AQueous One Solution Cell Proliferation Assay (Promega, Madison, WI, USA), according to the manufacturer's protocol. Each treatment within a single experiment was performed in triplicate. Absorbance at $490 \mathrm{~nm}$ was recorded using a Wallac 1420 VICTOR2 plate reader (PerkinElmer, Waltham, MA, USA). Data were normalized to the untreated control.

\subsection{Cell Count}

Floating and trypsinized cells were collected and suspended in fresh medium at room temperature. Twenty microliters of cell suspension was mixed with $20 \mu \mathrm{L}$ of $0.4 \%$ Trypan blue solution (Bio-Rad, Carlsbad, CA, USA), and $20 \mu \mathrm{L}$ of this mixture was used to count blue (dead) and white (alive) cells.

\subsection{Analysis of Drug Interaction}

The nature of the interactions between the drugs studied was analyzed with the help of combination-index (CI) methods, derived from the median-effect principle of Chou and Talalay [49]. CI values indicate the following: $<0.1$, very strong synergism; $0.1-0.3$, strong synergism; $0.3-0.7$, synergism; $0.7-0.85$, moderate synergism; $0.85-0.9$, slight synergism; $0.9-1.1$, nearly additive; $1.1-1.2$, slight antagonism; 1.2-1.45, moderate antagonism; $1.45-3.3$, antagonism; $3.3-10$, strong antagonism; $>10$, very strong antagonism. The CI value was calculated using CompuSyn software (ComboSyn, Inc., Paramus, NJ, USA). The CI was defined as follows: CI = (D) $1 /(\mathrm{Dx}) 1+(\mathrm{D}) 2 /(\mathrm{Dx}) 2$ for mutually exclusive drugs. In the denominator, (Dx) is for D1 "alone" that inhibits a system $\mathrm{x} \%$, and (Dx) 2 is for D2 "alone" that inhibits a system $\mathrm{x} \%$. In the numerators, (D) $1+(\mathrm{D}) 2$ "in combination" also inhibit $\mathrm{x} \%$.

\subsection{Annexin V Staining}

Apoptosis was assessed by the Annexin V Apoptosis Detection Kit (Santa Cruz Biotechnology, Dallas, TX, USA), according to the manufacturer's protocol. Briefly, the cells were stained with annexin V-FITC $(8 \mu \mathrm{g} / \mathrm{mL})$ and PI $(5 \mu \mathrm{g} / \mathrm{mL})$ for $15 \mathrm{~min}$ at RT in the dark. The cells were washed with cold PBS (with $\mathrm{Ca}^{2+}$ and $\mathrm{Mg}^{2+}$ ) containing 2.5\% FBS between the steps. Data were acquired using a FACSCalibur flow cytometer (Becton Dickinson, Franklin Lakes, NJ, USA) and analyzed using Flowing Software 2.5.1 (Perttu Terho, Turku, Finland). Apoptosis was quantified as a percentage of both annexin V-positive and annexin V/PI-double-positive cells.

\subsection{Cell Cycle and DNA Fragmentation Assay}

The cells were fixed in $75 \%$ ethanol at $4{ }^{\circ} \mathrm{C}$ for $30 \mathrm{~min}$, and then incubated with $50 \mathrm{ng} / \mathrm{mL}$ PI staining solution and $0.2 \mathrm{mg} / \mathrm{mL}$ RNase in the dark overnight at $4{ }^{\circ} \mathrm{C}$. Data were acquired using a 
FACSCalibur flow cytometer (Becton Dickinson, Franklin Lakes, NJ, USA) and analyzed using the ModFit LT 5.0 software (Verity Software House, Inc., Topsham, ME, USA).

\subsection{Western Blotting}

Whole cell lysates were prepared using cold RIPA buffer (150 mM NaCl (POCH), $50 \mathrm{mM}$ Tris-HCl pH 8.0 (BioShop, Burlington, ON, Canada), 1\% NP-40 (Calbiochem, San Diego, CA, USA), 0.5\% sodium deoxycholate (Sigma-Aldrich, St. Louis, MO, USA), and 1\% SDS (BioShop, Burlington, ON, Canada)) supplemented with SigmaFAST Protease Inhibitor Cocktail (Sigma-Aldrich, St. Louis, MO, USA) and Halt Phosphatase Inhibitor Cocktail (Thermo Fisher Scientific, Waltham, MA, USA). Cell lysates were then sonicated for $10 \mathrm{~s}$ at $100 \%$ power using a Sonopuls HD 2070 ultrasonic homogenizer (Bandelin, Berlin, Germany) and centrifuged at $10,000 \times \mathrm{g}$ for $10 \mathrm{~min}$ at $4{ }^{\circ} \mathrm{C}$ to pellet cellular debris. Protein concentration was determined by the Pierce BCA Protein Assay Kit (Thermo Fisher Scientific, Waltham, MA, USA), according to the manufacturer's protocol. Absorbance at $570 \mathrm{~nm}$ was recorded using a Wallac 1420 VICTOR2 plate reader. Cell lysates with Laemmli sample buffer (50 mM Tris-HCl pH 6.8, 10\% glycerol (BioShop, Burlington, ON, Canada), 5\% 2-mercaptoethanol (Sigma-Aldrich, St. Louis, MO, USA), $2 \%$ SDS, $0.05 \%$ bromophenol blue (BioShop, Burlington, ON, Canada)) were heated for 5 min at $95^{\circ} \mathrm{C}$, the proteins were separated by SDS-PAGE using $8-12 \%$ resolving gels (SDS-PAGE running buffer: $25 \mathrm{mM}$ Tris, $192 \mathrm{mM}$ glycine (BioShop Burlington, ON, Canada), 0.1\% SDS) and transferred (semidry transfer) to a PVDF membrane ( $0.45 \mu \mathrm{m}$ pore size; Merck Millipore) (transfer buffer: $25 \mathrm{mM}$ Tris, $192 \mathrm{mM}$ glycine, and either $10 \%$ or $20 \%$ methanol (POCH)). In between the steps, membranes were washed with TBST ( $20 \mathrm{mM}$ Tris, $150 \mathrm{mM} \mathrm{NaCl}, 0.1 \%$ Tween 20 (BioShop, Burlington, ON, Canada)). Membranes were blocked either with $1 \%$ casein $(0.1 \mathrm{M}$ Tris- $\mathrm{HCl} \mathrm{pH} \mathrm{8.0,} 214 \mathrm{mM} \mathrm{NaCl}, 1 \%$ casein from bovine milk (Sigma-Aldrich, St. Louis, MO, USA)) or 5\% BSA/TBST (Sigma-Aldrich, St. Louis, MO, USA) for an hour at RT or overnight at $4{ }^{\circ} \mathrm{C}$ and then incubated with primary antibody overnight at $4{ }^{\circ} \mathrm{C}$. After probing with HRP-conjugated secondary antibody for $1 \mathrm{~h}$ at RT, proteins of interest were detected using SuperSignal West Dura Extended Duration Substrate (Thermo Fisher Scientific, Waltham, MA, USA). The following antibodies were used in this study: anti-p21/HRP (1:1000, \#sc-6246; Santa Cruz Biotechnology, Dallas, TX, USA), anti-c-Myc (1:1000, \#sc-788; Santa Cruz Biotechnology, Dallas, TX, USA), anti-cyclin D1 (1:1000, \#2978; Cell Signaling Technology, Danvers, MA, USA), anti-cyclin B1 (1:2000, \#4135; Cell Signaling Technology, Danvers, MA, USA ), anti-Akt (1:1000, \#4691; Cell Signaling Technology, Danvers, MA, USA), anti-phospho-Akt (1:1000, \#4060; Cell Signaling Technology, Danvers, MA, USA), anti-ERK1/2 (1:1000, \#9102; Cell Signaling Technology, Danvers, MA, USA), anti-phospho-ERK1/2 (1:1000, \#9101; Cell Signaling Technology, Danvers, MA, USA), anti-actin/HRP (1:2000, \#sc-1615; Santa Cruz Biotechnology, Dallas, TX, USA), anti-mouse/HRP (1:2000, \#P0447; Dako, Glostrup, Denmark), and anti-rabbit/HRP (1:2000-3000, \#P0048; Dako, Glostrup, Denmark).

\subsection{Long-Term Colony-Formation Assay}

Viable cells were counted using the trypan blue method and seeded in duplicate at a density of $5 \times 10^{2}$ cells $/ 6 \mathrm{~mL}\left(21 \mathrm{~cm}^{2}\right)$. The dishes had been precoated with poly-L-lysine/PBS $(0.001 \%$; Sigma-Aldrich, St. Louis, MO, USA) and washed twice with PBS (with $\mathrm{Ca}^{2+}$ and $\mathrm{Mg}^{2+}$ ). After 2 weeks, the colonies were fixed and stained with $1 \%$ crystal violet/ethanol (Sigma-Aldrich, St. Louis, MO, USA), documented with an Olympus Stylus SH-50 camera (Olympus, Tokyo, Japan), and counted manually using the Image 1.47 software (National Institutes of Health, Bethesda, MD, USA). The term plating efficiency $(\mathrm{PE})$ indicates the percentage of seeded cells that grow to form colonies. The surviving fraction (SF) is calculated as the ratio between the PEs of treated and control cells multiplied by 100 .

\subsection{Statistical Analysis}

Data are presented as means \pm SD of the results from at least three independent experiments. Comparisons between the two groups: sorafenib treatment group vs. combinatorial treatment group, 
and betulinic acid treatment group vs. combinatorial treatment group, were analyzed by a two-tailed Student's $t$-test. The significance was assumed at ${ }^{*} p<0.05,{ }^{* *} p<0.01$.

Author Contributions: Conceptualization, L.S. and A.R.; Data curation, J.K.; Formal analysis, J.K.; Methodology, J.K., and L.S.; Project administration, A.R.; Supervision, L.S. and A.R.; Writing-original draft, J.K.; Writing-review \& editing, L.S. and A.R.

Funding: This work was supported by a grant from the Polish Academy of Sciences No. 03/2017 and by the Wroclaw Centre of Biotechnology programme of The Leading National Research Centre (KNOW) for the years 2014-2018.

Acknowledgments: We thank Ewa Ziolo for her technical assistance in cell culture.

Conflicts of Interest: The authors declare that they have no conflicts of interest with the content of this article.

$\begin{array}{ll}\text { Abbreviations } & \\ \text { PDAC } & \text { pancreatic ductal adenocarcinoma } \\ \text { PBL } & \text { peripheral blood lymphocytes } \\ \text { RAS } & \text { retrovirus-associated DNA sequences } \\ \text { MAPK } & \text { mitogen-activated protein kinase pathway } \\ \text { PI3K } & \text { phosphoinositide-3-kinase } \\ \text { AKT } & \text { protein kinase B } \\ \text { RAF } & \text { v-raf 1 murine leukemia viral oncogene homolog 1 } \\ \text { BRAF } & \text { v-Raf murine sarcoma viral oncogene homolog B } \\ \text { VEGFR-2 } & \text { vascular endothelial growth factor receptor-2 } \\ \text { PDGFR-b } & \text { platelet-derived growth factor receptor-b } \\ \text { FLT3 } & \text { Fms-related tyrosine kinase 3 } \\ \text { c-KIT } & \text { cell growth factor receptor Kit } \\ \text { c-MYC } & \text { transcription factor Myc } \\ \text { MTS } & \text { 3-(4,5-dimethylthiazol-2-yl)-5-(3-carboxymethoxyphenyl)-2-(4-sulfophenyl)-2H-tetrazolium } \\ \text { PI } & \text { propidium iodide } \\ \text { RT } & \text { room temperature } \\ \text { PBS } & \text { phosphate-buffered saline } \\ \text { FBS } & \text { fetal bovine serum }\end{array}$

\section{References}

1. Siegel, R.L.; Miller, K.D.; Jemal, A. Cancer statistics, 2017. CA Cancer J. Clin. 2017, 67, 7-30. [CrossRef] [PubMed]

2. Hidalgo, M. Pancreatic cancer. N. Engl. J. Med. 2010, 362, 1605-1617. [CrossRef] [PubMed]

3. Wolfgang, C.L.; Herman, J.M.; Laheru, D.A.; Klein, A.P.; Erdek, M.A.; Fishman, E.K.; Hruban, R.H. Recent progress in pancreatic cancer. CA Cancer J. Clin. 2013, 63, 318-348. [CrossRef] [PubMed]

4. Kreutzer, J.N.; Ruzzene, M.; Guerra, B. Enhancing chemosensitivity to gemcitabine via rna interference targeting the catalytic subunits of protein kinase CK2 in human pancreatic cancer cells. BMC Cancer 2010, 10, 440. [CrossRef] [PubMed]

5. Hsueh, C.T. Pancreatic cancer: Current standards, research updates and future directions. J. Gastrointest. Oncol. 2011, 2, 123-125. [PubMed]

6. Kutkowska, J.; Strzadala, L.; Rapak, A. Synergistic activity of sorafenib and betulinic acid against clonogenic activity of non-small cell lung cancer cells. Cancer Sci. 2017, 108, 2265-2272. [CrossRef] [PubMed]

7. Caldas, C.; Kern, S.E. K-ras mutation and pancreatic adenocarcinoma. Int. J. Pancreatol. 1995, 18, 1-6. [PubMed]

8. McCormick, F. Kras as a therapeutic target. Clin. Cancer Res. 2015, 21, 1797-1801. [CrossRef] [PubMed]

9. Hayes, T.K.; Neel, N.F.; Hu, C.; Gautam, P.; Chenard, M.; Long, B.; Aziz, M.; Kassner, M.; Bryant, K.L.; Pierobon, M.; et al. Long-term ERK inhibition in kras-mutant pancreatic cancer is associated with Myc degradation and senescence-like growth suppression. Cancer Cell 2016, 29, 75-89. [CrossRef] [PubMed] 
10. Wilhelm, S.M.; Carter, C.; Tang, L.; Wilkie, D.; McNabola, A.; Rong, H.; Chen, C.; Zhang, X.; Vincent, P.; McHugh, M.; et al. BAY 43-9006 exhibits broad spectrum oral antitumor activity and targets the $\mathrm{RAF} / \mathrm{MEK} / \mathrm{ERK}$ pathway and receptor tyrosine kinases involved in tumor progression and angiogenesis. Cancer Res. 2004, 64, 7099-7109. [CrossRef] [PubMed]

11. Adnane, L.; Trail, P.A.; Taylor, I.; Wilhelm, S.M. Sorafenib (BAY 43-9006, nexavar), a dual-action inhibitor that targets RAF/MEK/ERK pathway in tumor cells and tyrosine kinases VEGFR/PDGFR in tumor vasculature. Methods Enzymol. 2006, 407, 597-612. [PubMed]

12. Bruix, J.; Raoul, J.L.; Sherman, M.; Mazzaferro, V.; Bolondi, L.; Craxi, A.; Galle, P.R.; Santoro, A.; Beaugrand, M.; Sangiovanni, A.; et al. Efficacy and safety of sorafenib in patients with advanced hepatocellular carcinoma: Subanalyses of a phase III trial. J. Hepatol. 2012, 57, 821-829. [CrossRef] [PubMed]

13. Escudier, B.; Eisen, T.; Stadler, W.M.; Szczylik, C.; Oudard, S.; Staehler, M.; Negrier, S.; Chevreau, C.; Desai, A.A.; Rolland, F.; et al. Sorafenib for treatment of renal cell carcinoma: Final efficacy and safety results of the phase iii treatment approaches in renal cancer global evaluation trial. J. Clin. Oncol. 2009, 27, 3312-3318. [CrossRef] [PubMed]

14. Goncalves, A.; Gilabert, M.; Francois, E.; Dahan, L.; Perrier, H.; Lamy, R.; Re, D.; Largillier, R.; Gasmi, M.; Tchiknavorian, X.; et al. Baypan study: A double-blind phase III randomized trial comparing gemcitabine plus sorafenib and gemcitabine plus placebo in patients with advanced pancreatic cancer. Ann. Oncol. 2012, 23, 2799-2805. [CrossRef] [PubMed]

15. Cardin, D.B.; Goff, L.; Li, C.I.; Shyr, Y.; Winkler, C.; DeVore, R.; Schlabach, L.; Holloway, M.; McClanahan, P.; Meyer, K.; et al. Phase II trial of sorafenib and erlotinib in advanced pancreatic cancer. Cancer Med. 2014, 3, 572-579. [CrossRef] [PubMed]

16. Newman, D.; Cragg, G. Natural products in medicinal chemistry. Bioorg. Med. Chem. 2009, 17, 2120. [CrossRef] [PubMed]

17. Rios, J.L.; Manez, S. New pharmacological opportunities for betulinic acid. Planta Med. 2018, 84, 8-19. [CrossRef] [PubMed]

18. Goswami, P.; Paul, S.; Banerjee, R.; Kundu, R.; Mukherjee, A. Betulinic acid induces DNA damage and apoptosis in siha cells. Mutat. Res. 2018, 828, 1-9. [CrossRef] [PubMed]

19. Xu, T.; Pang, Q.; Wang, Y.; Yan, X. Betulinic acid induces apoptosis by regulating PI3K/AKT signaling and mitochondrial pathways in human cervical cancer cells. Int. J. Mol. Med. 2017, 40, 1669-1678. [CrossRef] [PubMed]

20. Pandita, A.; Kumar, B.; Manvati, S.; Vaishnavi, S.; Singh, S.K.; Bamezai, R.N. Synergistic combination of gemcitabine and dietary molecule induces apoptosis in pancreatic cancer cells and down regulates PKM2 expression. PLoS ONE 2014, 9, e107154. [CrossRef] [PubMed]

21. Deer, E.L.; Gonzalez-Hernandez, J.; Coursen, J.D.; Shea, J.E.; Ngatia, J.; Scaife, C.L.; Firpo, M.A.; Mulvihill, S.J. Phenotype and genotype of pancreatic cancer cell lines. Pancreas 2010, 39, 425-435. [CrossRef] [PubMed]

22. Kaufman, J.M.; Yamada, T.; Park, K.; Timmers, C.D.; Amann, J.M.; Carbone, D.P. A transcriptional signature identifies LKB1 functional status as a novel determinant of mek sensitivity in lung adenocarcinoma. Cancer Res. 2017, 77, 153-163. [CrossRef] [PubMed]

23. El-Rayes, B.F.; Ali, S.; Ali, I.F.; Philip, P.A.; Abbruzzese, J.; Sarkar, F.H. Potentiation of the effect of erlotinib by genistein in pancreatic cancer: The role of akt and nuclear factor-kappab. Cancer Res. 2006, 66, 10553-10559. [CrossRef] [PubMed]

24. Zhang, Y.; Yan, W.; Collins, M.A.; Bednar, F.; Rakshit, S.; Zetter, B.R.; Stanger, B.Z.; Chung, I.; Rhim, A.D.; di Magliano, M.P. Interleukin-6 is required for pancreatic cancer progression by promoting MAPK signaling activation and oxidative stress resistance. Cancer Res. 2013, 73, 6359-6374. [CrossRef] [PubMed]

25. Heinemann, V.; Quietzsch, D.; Gieseler, F.; Gonnermann, M.; Schonekas, H.; Rost, A.; Neuhaus, H.; Haag, C.; Clemens, M.; Heinrich, B.; et al. Randomized phase III trial of gemcitabine plus cisplatin compared with gemcitabine alone in advanced pancreatic cancer. J. Clin. Oncol. 2006, 24, 3946-3952. [CrossRef] [PubMed]

26. Berlin, J.D.; Catalano, P.; Thomas, J.P.; Kugler, J.W.; Haller, D.G.; Benson, A.B., 3rd. Phase iii study of gemcitabine in combination with fluorouracil versus gemcitabine alone in patients with advanced pancreatic carcinoma: Eastern cooperative oncology group trial E2297. J. Clin. Oncol. 2002, 20, 3270-3275. [CrossRef] [PubMed] 
27. El-Khoueiry, A.B.; Ramanathan, R.K.; Yang, D.Y.; Zhang, W.; Shibata, S.; Wright, J.J.; Gandara, D.; Lenz, H.J. A randomized phase ii of gemcitabine and sorafenib versus sorafenib alone in patients with metastatic pancreatic cancer. Investig. New Drugs 2012, 30, 1175-1183. [CrossRef] [PubMed]

28. Aparicio, J.; Garcia-Mora, C.; Martin, M.; Petriz, M.L.; Feliu, J.; Sanchez-Santos, M.E.; Ayuso, J.R.; Fuster, D.; Conill, C.; Maurel, J. A phase I, dose-finding study of sorafenib in combination with gemcitabine and radiation therapy in patients with unresectable pancreatic adenocarcinoma: A grupo espanol multidisciplinario en cancer digestivo (GEMCAD) study. PLoS ONE 2014, 9, e82209. [CrossRef] [PubMed]

29. Saif, M.W. Pancreatic cancer: Sorafenib: No effect on efficacy of chemotherapy in pancreatic cancer. Nat. Rev. Gastroenterol. Hepatol. 2014, 11, 8-9. [CrossRef] [PubMed]

30. Li, L.; Du, Y.; Kong, X.; Li, Z.; Jia, Z.; Cui, J.; Gao, J.; Wang, G.; Xie, K. Lamin b1 is a novel therapeutic target of betulinic acid in pancreatic cancer. Clin. Cancer Res. 2013, 19, 4651-4661. [CrossRef] [PubMed]

31. Gao, Y.; Jia, Z.; Kong, X.; Li, Q.; Chang, D.Z.; Wei, D.; Le, X.; Suyun, H.; Huang, S.; Wang, L.; et al. Combining betulinic acid and mithramycin a effectively suppresses pancreatic cancer by inhibiting proliferation, invasion, and angiogenesis. Cancer Res. 2011, 71, 5182-5193. [CrossRef] [PubMed]

32. Chintharlapalli, S.; Papineni, S.; Liu, S.; Jutooru, I.; Chadalapaka, G.; Cho, S.D.; Murthy, R.S.; You, Y.; Safe, S. 2-cyano-lup-1-en-3-oxo-20-oic acid, a cyano derivative of betulinic acid, activates peroxisome proliferator-activated receptor gamma in colon and pancreatic cancer cells. Carcinogenesis 2007, 28, 2337-2346. [CrossRef] [PubMed]

33. Pyo, C.W.; Choi, J.H.; Oh, S.M.; Choi, S.Y. Oxidative stress-induced cyclin D1 depletion and its role in cell cycle processing. Biochim. Biophys. Acta 2013, 1830, 5316-5325. [CrossRef] [PubMed]

34. Hitomi, M.; Yang, K.; Stacey, A.W.; Stacey, D.W. Phosphorylation of cyclin D1 regulated by ATM or ATR controls cell cycle progression. Mol. Cell. Biol. 2008, 28, 5478-5493. [CrossRef] [PubMed]

35. Yang, K.; Hitomi, M.; Stacey, D.W. Variations in cyclin D1 levels through the cell cycle determine the proliferative fate of a cell. Cell Div. 2006, 1, 32. [CrossRef] [PubMed]

36. Hessmann, E.; Schneider, G.; Ellenrieder, V.; Siveke, J.T. MYC in pancreatic cancer: Novel mechanistic insights and their translation into therapeutic strategies. Oncogene 2016, 35, 1609-1618. [CrossRef] [PubMed]

37. Seo, H.K.; Ahn, K.O.; Jung, N.R.; Shin, J.S.; Park, W.S.; Lee, K.H.; Lee, S.J.; Jeong, K.C. Antitumor activity of the c-Myc inhibitor KSI-3716 in gemcitabine-resistant bladder cancer. Oncotarget 2014, 5, 326-337. [CrossRef] [PubMed]

38. Demeterco, C.; Itkin-Ansari, P.; Tyrberg, B.; Ford, L.P.; Jarvis, R.A.; Levine, F. c-Myc controls proliferation versus differentiation in human pancreatic endocrine cells. J. Clin. Endocrinol. Metab. 2002, 87, 3475-3485. [CrossRef] [PubMed]

39. Hoffman, B.; Liebermann, D.A. Apoptotic signaling by c-Myc. Oncogene 2008, 27, 6462-6472. [CrossRef] [PubMed]

40. Parveen, A.; Akash, M.S.; Rehman, K.; Kyunn, W.W. Dual role of p21 in the progression of cancer and its treatment. Crit. Rev. Eukaryot. Gene Expr. 2016, 26, 49-62. [CrossRef] [PubMed]

41. Nelsen, C.J.; Kuriyama, R.; Hirsch, B.; Negron, V.C.; Lingle, W.L.; Goggin, M.M.; Stanley, M.W.; Albrecht, J.H. Short term cyclin $\mathrm{d} 1$ overexpression induces centrosome amplification, mitotic spindle abnormalities, and aneuploidy. J. Biol. Chem. 2005, 280, 768-776. [CrossRef] [PubMed]

42. Bachmann, K.; Neumann, A.; Hinsch, A.; Nentwich, M.F.; El Gammal, A.T.; Vashist, Y.; Perez, D.; Bockhorn, M.; Izbicki, J.R.; Mann, O. Cyclin D1 is a strong prognostic factor for survival in pancreatic cancer: Analysis of CD G870A polymorphism, fish and immunohistochemistry. J. Surg. Oncol. 2015, 111, 316-323. [CrossRef] [PubMed]

43. Garcia, Z.; Kumar, A.; Marques, M.; Cortes, I.; Carrera, A.C. Phosphoinositide 3-kinase controls early and late events in mammalian cell division. EMBO J. 2006, 25, 655-661. [CrossRef] [PubMed]

44. Yun, S.M.; Jung, K.H.; Lee, H.; Son, M.K.; Seo, J.H.; Yan, H.H.; Park, B.H.; Hong, S.; Hong, S.S. Synergistic anticancer activity of HS-173, a novel PI3K inhibitor in combination with sorafenib against pancreatic cancer cells. Cancer Lett. 2013, 331, 250-261. [CrossRef] [PubMed]

45. Junttila, M.R.; Devasthali, V.; Cheng, J.H.; Castillo, J.; Metcalfe, C.; Clermont, A.C.; Otter, D.D.; Chan, E.; Bou-Reslan, H.; Cao, T.; et al. Modeling targeted inhibition of MEK and PI3 kinase in human pancreatic cancer. Mol. Cancer Ther. 2015, 14, 40-47. [CrossRef] [PubMed] 
46. Alagesan, B.; Contino, G.; Guimaraes, A.R.; Corcoran, R.B.; Deshpande, V.; Wojtkiewicz, G.R.; Hezel, A.F.; Wong, K.K.; Loda, M.; Weissleder, R.; et al. Combined MEK and PI3K inhibition in a mouse model of pancreatic cancer. Clin. Cancer Res. 2015, 21, 396-404. [CrossRef] [PubMed]

47. Matsui, W.; Huff, C.A.; Wang, Q.; Malehorn, M.T.; Barber, J.; Tanhehco, Y.; Smith, B.D.; Civin, C.I.; Jones, R.J. Characterization of clonogenic multiple myeloma cells. Blood 2004, 103, 2332-2336. [CrossRef] [PubMed]

48. Dou, J.; Li, Y.; Zhao, F.; Hu, W.; Wen, P.; Tang, Q.; Chu, L.; Wang, Y.; Cao, M.; Jiang, C.; et al. Identification of tumor stem-like cells in a mouse myeloma cell line. Cell. Mol. Biol. 2009. [CrossRef]

49. Chou, T.C.; Talalay, P. Quantitative analysis of dose-effect relationships: The combined effects of multiple drugs or enzyme inhibitors. Adv. Enzym. Regul. 1984, 22, 27-55. [CrossRef]

(C) 2018 by the authors. Licensee MDPI, Basel, Switzerland. This article is an open access article distributed under the terms and conditions of the Creative Commons Attribution (CC BY) license (http://creativecommons.org/licenses/by/4.0/). 